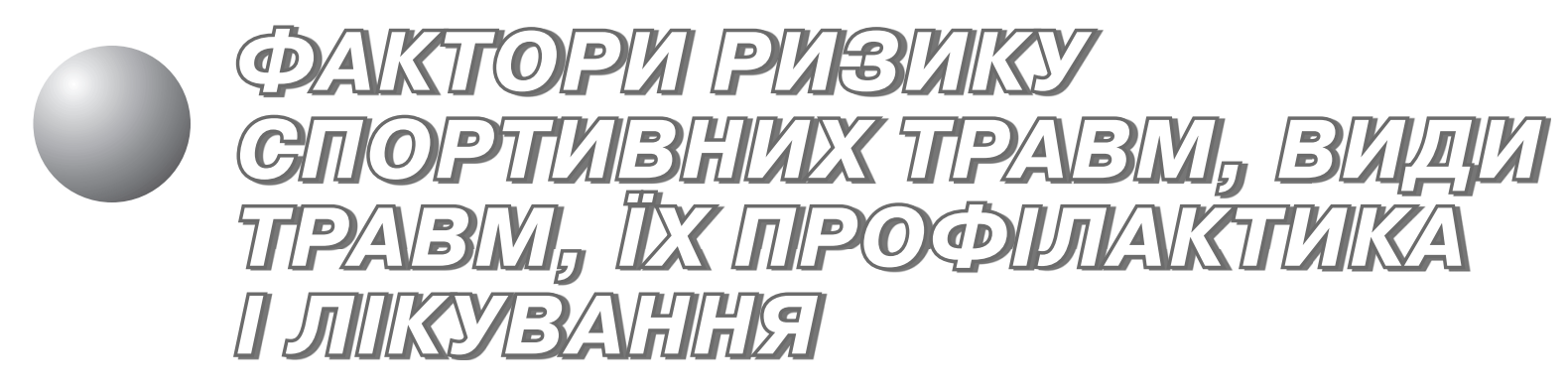

\title{
Лікування остеоартрозу спортсменів за допомогою хондропротектора «Остеоартізі актив плюс»
}

\section{В. Н. Левенець}

Національний університет фізичного виховання і спорту України, Київ, Україна

\begin{abstract}
Резюме. В работе представлены данные остеоартроза у спортсменов. На основании исследований подчеркнута важность определения доклинической формы заболевания - предартроза, которую автор совместно с проф. Ф. Р. Богдановым предложил в 1973 г. Предартроз определяется наличием синовита, менискоза (дегенеративно-дистрофическими изменениями), сонографическим выявлением, МРТ устанавливает изменения структуры мениска за счет неравномерности, снижение высоты суставного хряща, уменьшение менискального пространства и выход паракапсулярной части за пределы суставной щели. Проведенное в течение трех месяцев лечение путем перорального приема хондропротектора II-III ряда “Остеоартизи актив плюс» фирмы ARM (Australia) позитивно повлияло на состояние коленного сустава 27 спортсменов: на протяжении 12 месяцев боль уменьшилась, а у некоторых исчезла; остальные показатели (сонографические и МРT) засвидетельствовали стабилизацию процесса.
\end{abstract}

Ключевые слова: остеоартроз, спортсмены, хондропротектор «Остеартизи актив плюс».

\begin{abstract}
Summary. The paper presents the data on osteoarthritis in athletes. On the basis of previous studies, significance of determining preclinical form of disease, a pre-arthritis, which was suggested and reported by the author together with professor F.R.Bogdanov in 1973, was emphasised. Prearthrosis is determined by presence of synovitis, meniscosis (degenerative-dystrophic changes), and sonographic detection. MRI determines changes in meniscus structure resulted from irregularity, decrease of articular cartridge height, reduction of meniscal space and protrusion of paracapsular part beyond the limits of articular cavity. Three months of peroral treatment by "Osteoartisi Active plus» ARM (Australia), belonging to chondroprotectors of the II-III order, has positively influenced the state of knee joints in 27 athletes; pain has decreased or disappeared within 12 months; other indices (sonographic and MRI) have indicated stabilization of the process.
\end{abstract}

Key words: osteoarthritis, athletes, chondroprotectors, «Osteoartisi active plus».

Найбільш складною і найменш розробленою проблемою спортивної травматології $\epsilon$ ушкодження суглобового хряща, зокрема питання механізму, діагностики, лікування і профрілактичних ускладнень, особливо остеоартрозу (ОА), що викликає часткову, а іноді й повну втрату спортивної працездатності [3].

Проблема суглобового хряща набула актуальності останніми роками, коли накреслилась тенденція розширення професійного спорту, що потребує більш значного навантаження, а отже підвищення ризику більш частого травмування [2-4].

За даними багатьох авторів і нашими спостереженнями, ушкодження суглобового хряща колінного, кульшового, надп'ятково-гомілкового i, меншою мірою, ліктьового та плечового суглобів - одна з безпосередніх причин розвитку 
остеоартрозу внаслідок низьких здібностей суглобового хряща до репаративної регенерації і порушень синовіального середовища, що дає можливість вважати ушкодження суглобового хряща стадією передартрозну [1, 5, 8, 9].

Аналіз комплексного - клініко-лабораторного сонографрічного, магнітно-резонасного і артроскопічного - дослідження збірної Олімпійської команди України у 2002 р. показав наявність у окремих спортсменів ознак дегенеративно-дистрофрічного процесу, що при відсутності клінічних скарг на колінний суглоб укладаються в поняття ОА.

В останні роки в Україні і за її межами [1, 5, 8, 9] в літературі все частіше зустрічається термін «передартроз», який ми разом 3 профресором Ф. Р. Богдановим вперше у світі запропонували у 1974 р. у збірнику наукових робіт НДІ травматології, ортопедії і відновлювальної хірургіï Свердловська.

Вплив видалення менісків при їх ушкодженні вивчав в 1975 р. Сахно Г. П. і підтвердив, що у окремих спортсменів і осіб, які виконували важку працю з великими навантаженнями (але не займались спортом), за відсутності рентгенологічних даних виявились макро- і мікроскопічні ознаки ОА: наявність синовіту, який періодично виникав у пацієнтів; мікроскопічні зміни блакитного кольору суглобового хряща на білястий; шершавість хряща і дрібні тріщини його поверхні. Автор звернув увагу на те, що при відсутності лікування протягом $1-1,5$ років або при неадекватному лікуванні в суглобі розвивався типовий ОА з чіткими рентгенологічними ознаками: зниженням висоти суглобової щілини, субхондральним склерозом, бічним кістковим розростанням та кістковоподібною перебудовою. Він також довів, що одноразова гостра і багаторазова хронічна травми суглоба збільшують та прискорюють перебіг ОА, а видалення меніска у різні терміни не тільки не припиняє, але також погіршує i ускладнює перебіг ОА.

На думку багатьох авторів [2, 6, 9], пошкодження суглобового хряща $є$ однією з головних безпосередніх причин розвитку ОА внаслідок дегенеративних процесів, які з часом виникають у його тканинах.

Меніскальний остеоартроз має свої особливості перебігу. Його клінічні прояви через 8-10 місяців після травми характеризувались больовими, руховими і трофрічними розладами. Рентгенологічні ознаки визначались асиметричним склерозом субхондрального шару, зниженням висоти суглобової щілини на боці ушкодженого меніска і через рік виявились як бічні кісткові розрощення, а у більш пізні терміни навіть скривлення вісі кінцівки.

Наш багаторічний досвід лікування спортсменів з ушкодженнями і захворюваннями внутрішньосуглобових структур колінного суглоба доводить, що тільки своєчасна діагностика, адекватне лікування і реабілітація дозволяють попередити розвиток і прогресування ОА.

Порушення цілісності медіального і латерального менісків $\epsilon$ серйозним ушкодженням, що значно порушує фрункцію колінного суглоба, часто призводить до розвитку ОА у спортсменів. Причину ОА визначали за безпосереднім впливом ушкодженого меніска на суглобовий хрящ виростків стегнової і великогомілкової кісток, надколінка, навантажувальної поверхні стегнової кістки.

Механізм ушкоджень суглобового хряща у спортсменів досить різний, неоднозначний i складний. Найчастіше фрактори ушкодження суглобового хряща: хронічна мікротравма, що часто повторюється, гостра травма, синдром перевантаження, хронічна нестабільність, дисплатичні зміни, латеропозиція надколінка, ушкодження медіальної складки, надмірні та нехарактерні рухи, вільні внутрішньосуглобові хрящові, кісткові та інородні тіла.

Для різних локалізацій суглобових поверхонь характерні різні механізми, на які впливають і види спорту. Так, у штангістів частіше ушкоджується пателофеморальний суглоб, а саме надколінок і його протилежна - «дзеркальна» - поверхня стегнової кістки. У фрутболістів, баскетболістів, хокеїстів найбільш травмується навантажувальна зона виростків стегна, меніски, великогомілкове подменіскальне плато. Стайєри страждають через ушкодження навантажувальних зон стегнової і великогомілкової кісток, а стрибуни ще й хряща надколінка.

Визначення ОА було прийнято в 1995 р. на семінарі Американської академії хірургів-ортопедів, Національного інституту по проблемі остеоартрозу, Національного інституту проблем старіння, Фонду артриту та Фонду ортопедичних досліджень та навчання.

«Остеоартроз являє собою групу частково збіжних захворювань, які мають різну етиологію, але схожі біологічні, морфологічні і клінічні наслідки. Процеси не обмежуються лише суглобовим хрящем і включають увесь суглоб, субхондральну кістку, суглобову рідину і капсулу, зв'язки і білясуглобові м'язи. В остаточному підсумку визначається дегенерація суглобового хряща з фрібриляцією, утворенням тріщин і втратою щільності субхондральної кістки. Типовий ОА $є$ 
гетерогенним захворюванням і виникає внаслідок травм, нестабільності, різних вроджених, вікових або набутих порушень, що призводить до аномального навантаження на суглобовий хрящ».

Таким чином, ОА являє собою ушкодження синовіального середовища і будь-яке його утворення може бути першим, що підпадає під ушкодження.

Загальним механічним фрактором, що лежить в основі ОА, $€$ патологічне збільшення внутрішньосуглобового навантаження.

Зважаючи на те, що ОА - захворювання, основною причиною якого у спортсменів $\epsilon$ перевантаження або хронічна мікротравматизація, (тобто механічна причина), ми вважаємо за необхідне включати в лікувальний комплекс нормалізацію навантаження. Крім того, реактивне запалення і зміни клітинного механізму є невід'ємною частиною процесу відновлення.

Дані літератури свідчать: руйнування хряща у спортсменів спричинюється металопротеїназами матриксу, утворення яких стимулює інтерлейкін і фрактор некрозу пухлини; ці цитоніни можуть вироблятися хондроцитами у відповідь на механічне навантаження.

Хоча металопротеїнази можуть послабити механічну цілісність суглобового хряща при ОА, механічні фрактори, мабуть, грають головну роль, а саме фрармакологічне інгібіювання металопротеїназ з успіхом припинило прогресування ОА [6].

Останніми роками з'явились дослідження, які свідчать, що глюкозамін сульфрат, хондроїтин, гіалуронат натрію, інгібітори матриксної металопротеїнази можуть модифікувати прогресування захворювання ОА. На даному етапі ці складні сполуки «не виправдали надії» на ранній клінічній стадії захворювання.

Дослідження, виконані на тваринах, дали підставу вважати, що тетрацикліни знижують тяжкість ОА, мабуть, за рахунок інгібіювання ММР [7]. У дослідженні в клініці визначено затримання прогресування зменшення міжменіскального простору у пацієнтів з ОА.

Враховуючи дані про зв'язок між суглобовим хрящем, хрящовим матриксом, хондроцитами і протегліканами, а також те, що синовіальна рідина має важливі реологічні властивості - в'язкість, еластичність та ефект механічної губки, - в Центрі спортивної травматології було проведено дослідження з виявлення впливу хондропротекторів другого та третього покоління, а саме у вигляді препарату «Остеоартізі актив плюс» фрірми АРМ (Австралія), на пацієнтів і спортсменів. Препарат, на нашу думку, вигідно відрізняється від багатьох інших за рахунок складу, до якого входять глюкозаміна гідрохлорид, хондроїтин сульфат, екстрат селери пахучої, кори верби білої, кореня імбиру аптечного. Ці складники сприяють нормальній роботі опорно-рухової системи, зокрема, колінного суглоба, кісток та зв'язок.

В дослідженні брали участь 27 спортсменів, серед яких один заслужений майстер спорту, п'ять майстрів спорту міжнародного класу, 12 майстрів спорту, три кандидати в майстри спорту і шість I розряду. Вік коливався від 19 до 27, в середньому складав 23,3 років.

Клінічне обстеження перед лікуванням виявило біль після навантаження, синовіт періодично виникав у 11 спортсменів, що знайшло підтвердження сонографрічними дослідженнями. Із аналізу встановлено, що синовіт виникав після тренування, як правило, з елементами перевантаження. В дні, коли тренувань не було, синовіт виявлявся лише сонографрічно - за допомогою симптома Хаджистамова - лише у двох спортсменів, а під час відпочинку синовіт не визначався.

Сонографрічно у 13 спортсменів помічено порушення структури медіального меніска, яке проходило зі зміною нормальної структури. В менісках спостерігалась нерівномірна структура, що свідчить про дистрофрічний процес. Сонографрічно також визначено вихід тіла меніска за межі суглобової капсули. МРТ засвідчило зменшення висоти суглобового хряща, що в цілому ми розцінили як стадію передартрозу.

Препарат «Остеоартізі актив плюс» призначався двічі на добу по одній капсулі протягом трьох місяців. Контроль проводили через 12 місяців, коли у 19 спортсменів клінічно, сонографрічно було оцінено фуунцціональний стан суглоба за допомогою шкали ВАШ та індексу Лекена:

\begin{tabular}{|l|c|c|}
\hline \multicolumn{1}{|c|}{ Показник } & До лікування & Через 12 місяців \\
\hline Шкала ВАШ & $5,2 \pm 0,1$ & $2,3 \pm 0,2$ \\
\hline Індекс Лекена (згинання, град.) & $85 \pm 1,2$ & $45 \pm 1,6$ \\
\hline
\end{tabular}

\section{Висновки}

Після прийому препарату «Остеоартізі-активплюс» у всіх спортсменів біль зменшився майже удвічі при контролі через 12 місяців. Зменшення навантаження в періоди відпочинку сприяло цьому. Сонографічні дані: майже не змінилась картина стану менісків. Аналогічна також і картина даних МРТ. На цій підставі можна зробити висновок про те, що об'єктивні показники клінічних, сонографрічних і МРТ ознак свідчать про певне покращення стану колінного суглоба у спортсменів - позитивний вплив хондропротекторного 
препарату «Остеоартізі актив плюс». Але при перевантаженнях у спортсменів подібні курси треба проводити два рази протягом року. «Остеоартізі актив плюс» - біологічний, фрітотерапевтичний хондропротекторний препарат - ефективний

\section{Література}

1. БорткеВич О. П. Сучасні уявлення про терапію у пацієнтів 3 дегенеративними захворюваннями суглобів та хребта препаратами, що модулюють структуру хряща / О. П. Борткевич, Ю. В. Білявська. // Укр. мед. часопис. [Електр. наук. журн.] - 2008. - Т. 5, № 67. - Режим доступу: http://www.umj.com.ua/wpcontent/uploads/ archive $/ 67 /$ pdf / 1344 ukr. pdf

2. Левенец В. Н. Повреждение медиального мениска и деформирующий артроз коленного сустава / В. Н. Левенец, Г. П. Сахно // Ортопед., травмат. и протезир. - К.: Здоров'я, 1973. - Вып. 3. - С. 75-86.

3. ЛеВенеи В. Н. Десрормирующий артроз: учеб. пособие // В. Н. Левенец, В. В. Пляцко, Г. И. Герцен, А. П. Юрченко. - М.: ЦОЛИУВ, 1989. - 57 с.

4. Clegg D. O. Glucosamine, chondroitin sulfate, and the two in combination for painful knee osteoarthritis / [D. O. Clegg, D. I. Reda, Cl. Harris et al.] // N. Engl. J. Med. - 2006. - N 354 (8). - P. 795-808.

5. Day J. S. A decreased subchondral trabecular bone tissue elastic modulus is associated with pre-arthritic cartilage damage / J. S. Day [et al.] // J. Orthop. Res. - 2001. N 19 (5). - P. 914-918.

6. Felson D. T. The futility of current approaches to chondroprotection / D. T. Felson, Y. Kim // Arthitis. Rheum. 2007: 56: $1378-1383$.

7. Lippiello $L$. Collagen synthesis in tenocytes, ligament cells and chondrocytes exposed to a combination of glucosamine $\mathrm{HCl}$ and chondroitin sulfate / L. Lippiello / / Evid. Based Complement Alternat. Med. - 2007, Jun. - 4 (2). - P. 219224.

8. Valdes $A$. M. The additive effect of individual genes in predicting risk of knee osteoarthritis / A. M. Valdes, M. Doherty, T. D. Spector // Ann. Rheum. Dis. - 2008. N 67 (1). - P. 124-127.

9. Messent E. A. Tibial cancelious bone changes in patients with knee osteoarthritis. A short-term longitudinal study using Fractal Signature Analysis / E. A. Messent [et al.] / / Osteoarthr. Cartil. - 2005. - N 13 (6). - P. 463470. засіб лікування спортсменів у стадії передартрозу. Тому його слід рекомендувати для профілактики дегенеративно-дистрофрічних процесів, що дасть можливість продовжити спортивну працездатність.

\section{References}

1. Bortkevych O.P. Current views on the treatment of degenerative diseases of joints and of the spine with preparations modulating cartilage structure // O. P. Bortkevych, U. V. Biliavska / Ukrainskyi medychnyi chasopys [Electronic scientific journal]. - 2008. - N 5 (67). - Access mode: http://www.umj.com.ua/wpcontent/ uploads/archive /67/pdf/1344_ukr.pdf

2. Levenets $V$. N. Damage to the medial meniscus and deforming arthritis of the knee joint / V. N. Levenets, G. P. Sakhno // Orthopaedics, Traumatology and Prosthetics. - Kiev: Zdorovia, 1973. - Issue 3. - P. 7586.

3. Levenets V. N. Deforming arthritis: Study guide // V. N. Levenets, V. V. Pliatsko, G. I. Gertsen, A. P. Yurchenko. Moscow: Central Order of Lenin Advanced Training Medical Institute, 1989. - $57 \mathrm{p}$.

4. Clegg D. O. Glucosamine, chondroitin sulfate, and the two in combination for painful knee osteoarthritis / [D. O. Clegg, D. I. Reda, Cl. Harris et al.] // N. Engl. J. Med. - 2006. - N 354 (8). - P. 795-808.

5. Day J. S. A decreased subchondral trabecular bone tissue elastic modulus is associated with pre-arthritic cartilage damage / J. S. Day [et al.] // J. Orthop. Res. - 2001. N 19 (5). - P. 914-918.

6. Felson D. T. The futility of current approaches to chondroprotection / D. T. Felson, Y. Kim // Arthitis. Rheum. - 2007: 56: 1378-1383.

7. Lippiello $L$. Collagen synthesis in tenocytes, ligament cells and chondrocytes exposed to a combination of glucosamine $\mathrm{HCl}$ and chondroitin sulfate / L. Lippiello / / Evid. Based Complement Alternat. Med. - 2007, Jun. - 4 (2). - P. 219-224.

8. Valdes $A$. M. The additive effect of individual genes in predicting risk of knee osteoarthritis / A. M. Valdes, M. Doherty, T. D. Spector // Ann. Rheum. Dis. - 2008. N 67 (1). - P. 124-127.

9. Messent E. A. Tibial cancelious bone changes in patients with knee osteoarthritis. A short-term longitudinal study using Fractal Signature Analysis / E. A. Messent [et al.] // Osteoarthr. Cartil. - 2005. - N 13 (6). - P. 463-470. 